\title{
Implementasi Pembelajaran Daring dan Luring Saat Pandemi Covid 19
}

\author{
Dian Puspita Eka Putri \\ Fakultas Tarbiyah \\ IAIN Syaikh Abdurrahman Siddik Bangka Belitung \\ Bangka, Indonesia \\ dianpuspitaeka@iainsasbabel.ac.id
}

\begin{abstract}
This study aims to determine how the implementation of offline learning (outside the network) and online (in the network) which took place during the Covid 19 pandemic in the Bangka Belitung Islands region. The condition of the Covid 19 Pandemic requires educators to conduct learning at home. To support that, the teaching staffs apply offline or online learning. This study used qualitative research methods. Data collection techniques used during this study were triangulation interviews between teachers, students and parents. Then the data obtained are analyzed until conclusions are drawn. The results of this study indicate that the application of offline learning undertaken by teachers during the covid-19 pandemic, is by utilizing learning videos and offline smartphone applications that are downloaded from various sources. Then online learning is done by the teacher during Covid 19 by using online applications such as Whatsapp, Google Form, Zoom, Google Meet and others.
\end{abstract}

Keywords: Implementation, Offline Learning, Online Learning

\begin{abstract}
Abstrak
Penelitian ini bertujuan untuk mengetahui bagaimana implentasi pembelajaran luring (luar jaringan) dan daring (dalam jaringan) yang berlansung selama pandemic Covid 19 di wilayah Kepulauan Bangka Belitung. Kondisi Pandemi Covid 19 mengharuskan para tenaga pendidik untuk melakukan pembelajaran dirumah. Untuk menunjang itu para tenaga pendidik penerapkan pembelajaran luring atau daring. Penelitian ini menggunakan metode penelitian kualitatif. Teknik pengumpulan data yang dilakukan selama penelitian ini adalah wawancara triangulasi antara guru, siswa dan orang tua. Kemudian data yeng didapat di analisis hingga ditarik kesimpulan. Hasil penelitian ini menunjukkan bahwa penerapan pembelajaran luring yang dilakukan oleh guru selama pandemi covid-19, ialah dengan memanfaatkan video pembelajaran dan aplikasi smartphone offline yang diunduh dari berbagai sumber. Kemudian pembelajaran daring dilakukan oleh guru selama Covid 19 ialah dengan memanfaatkan aplikasi online seperti Whatsapp, Google Form, Zoom, Google Meet dan lain-lain.
\end{abstract}

Kata Kunci: Implementasi, Pembelajaran Luring, Pembelajaran Daring 


\section{A. Pendahuluan}

Situasi Pandemi Covid 19 yang melanda Dunia juga dihadapi oleh bangsa Indonesia. ${ }^{1}$ Akibatnya berbagai sektor kehidupan manusia mengalami perubahan yang signifikan. ${ }^{2}$ Dunia Pendidikan juga terpapar imbas saat pandemi Covid 19 ini. $^{3}$ Adapun perubahan yang terjadi terlihat jelas dari sistem pembelajaran atau proses Kegiatan Belajar Mengajar (KBM). ${ }^{4}$ Sistem pembelajaran sebelum pandemi Covid 19 dilakukan secara tatap muka lansung antara pendidik dan peserta didik. ${ }^{5}$ Dengan kata lain proses KBM dilakukan secara lansung. Namun selama pandemi Covid 19 sistem pembelajran dilakukan melaui media (perantara) pembelajaran

Dinas Pendidikan dan kebudayaan (Disdikbud) di lingkungan Kepulauan Bangka Belitung menghimbau kepada seluruh masyarakat untuk melakukan pembelajaran dari rumah selama pandemi Covid 19.6 Disdikbud juga mengeluarkan dua metode pelaksanaan proses kegiatan belajar mengajar. Yaitu metode pembelajran luring (luar jaringan) dan metode pembelajaran Daring (dalam jaringan). ${ }^{7}$ Proses kegiatan belajar yang dilakukan dengan memanfaatkan media atau keaadaan luar jaringan disebut dengan metode luring. ${ }^{8}$ Sedangkan proses kegiatan belajar mengajarnya memanfaatkan media

\footnotetext{
${ }^{1}$ Roberto Salu Situru, 'Pembelajaran Dalam Jaringan (Daring) Masa Pandemic Covid-19', Elementary Journal, vol. 3, no. 1 (2020), pp. 40-6.

${ }^{2}$ Wahyu Aji Fatma Dewi, 'Dampak Covid-19 terhadap implementasi pembelajaran daring di Sekolah Dasar', Edukatif: Jurnal Ilmu Pendidikan, vol. 2, no. 1 (2020), pp. 55-61.

3 Hamdan Husein Batubara and Delila Sari Batubara, 'Penggunaan Video Tutorial Untuk Mendukung Pembelajaran Daring Di Masa Pandemi Virus Corona', Muallimuna: Jurnal Madrasah Ibtidaiyah, vol. 5, no. 2 (2020), pp. 74-84.

${ }^{4}$ I. Gede Dharman Gunawan, 'Transformasi Televisi Sebagai Masa Pandemi Covid-19', COVID-19: Perspektif Pendidikan (Yayasan Kita Menulis, 2020), p. 79.

${ }^{5}$ Ridwan Sanjaya, 21 Refleksi Pembelajaran Daring di Masa Darurat (SCU Knowledge Media, 2020).

${ }^{6}$ Syamsul Arifin, 'Sekolah di Rumah', Arsip Publikasi Ilmiah Biro Administrasi Akademik (2020).

${ }^{7}$ Ida Yuniati Surtika, 'Praktik Merdeka Belajar dalam Situasi Covid-19 (Sebuah Pengalaman Memimpin dari Rumah dalam Situasi Pandemik Covid-19 di SMKN 1 Pacet)', simpuljuara, vol. 2, no. 2 (2020), pp. 66-72.

${ }^{8}$ Suyono Suyono, 'Manajemen Pembelajaran Berbasis Daring Dalam Rangka Memutus Mata Rantai Penularan Covid-19 Di Perguruan Tinggi Swasta Lembaga Layanan Perguruan Tinggi (LLDikti) Wilayah Vii', EdHumanistics: Jurnal Ilmu Pendidikan, vol. 5, no. 1 (Fakultas Ilmu Pendidikan Universitas Hasyim Asy'ari Tebuireng Jombang, 2020), pp. 662-6.
} 
pembelajaran dalam jaringan internet disebut dengan metode daring. ${ }^{9}$ Namun bagaimana implementasi pembelajaran luring dan daring ini dilakukan oleh tenaga pendidik. Hal ini masih menjadi perdebatan yang tiada henti. ${ }^{10}$ Berbagai alasan muncul menjadi pemicu pro dan kontranya metode pembelajaran ini. Hal ini dikarenakan berbagai faktor penunjang pembelajaran tersebut. Faktor dominan yang secara jelas menyebabkan pro kontra adalah faktor geografis ataupun faktor ekonomis. ${ }^{11}$

Dilihat dari faktor geografis wilayah Indonesia khususnya Kepulauan Bangka Belitung. Tidak semua wilayang memiliki akses jaringa internet yang baik, sebagai provinsi yang tergolong muda, Kepulauan Bangka Belitung masih terus melakukan pembangunan dan pengembangan daerahnya, begitupula dengan penyebaran jaringan internetnya. ${ }^{12}$ Oleh karena itu daerah yang belum terdampak pengembangan belum memiliki kualitas jaringan internet yang memadai untuk melakukan pembelajaran luring ataupun daring. Dilihat dari faktor ekonomi, penerapan pembelajaran ini membutuhkan berbagai peralatan yang tidak murah, peralatan pendukung tersebut berupa Smartphone, Kuota Internet dan lain sebagainya. Sehingga penerapan metode luring dan daring ini mejadi hal yang dilematis bagi sektor Pendidikan. ${ }^{13}$

Berdasarkan pemaparan diatas maka perlu dilakukan pengkajian bagaimana implentasi pembelajaran luring dan daring dapat dilakukan sebagai upaya alternatif proses kegiatan belajar mengajar selama masa pandemi Covid 19 berlansung. Sehingga penelitian ini diharpkan mampu memberikan

\footnotetext{
9 Ali Sadikin and Afreni Hamidah, 'Pembelajaran Daring di Tengah Wabah Covid-19', BIODIK, vol. 6, no. 2 (2020), pp. 109-19.

${ }^{10}$ Henry Aditia Rigianti, 'Kendala Pembelajaran Daring Guru Sekolah Dasar Di Banjarnegara', Elementary School: Jurnal Pendidikan dan Pembelajaran ke-SD-an, vol. 7, no. 2 (2020).

${ }^{11}$ Roman Andrianto Pangondian, Paulus Insap Santosa, and Eko Nugroho, "Faktor-Faktor Yang Mempengaruhi Kesuksesan Pembelajaran Daring Dalam Revolusi Industri 4.0," in Seminar Nasional Teknologi Komputer \& Sains (Sainteks), vol. 1, 2019.

12 Paraden Lucas Sidauruk, 'Peranan Komunikasi Dalam Implementasi Kebijakan Pusat Layanan Internet Kecamatan (Kasus di Provinsi Kepulauan Bangka Belitung)', Jurnal Penelitian Pos dan Informatika, vol. 3, no. 1 (2013), pp. 81-113.

${ }^{13}$ Pangondian, Santosa, and Nugroho, 'Faktor-Faktor Yang Mempengaruhi Kesuksesan Pembelajaran Daring Dalam Revolusi Industri 4.0'.
} 
gambaran bagaimana implementasi pembelajaran luring dan daring saat pandemi Covid 19.

Implementasi pembelajaran daring sejatinya menjadi alternatif yang dapat dijalankan selama masa pandemic Covid 19. Namun kendala berbagai sektor menjadikan pembelajaran daring dirasa sulit untuk dilakukan. Hal ini dapat ditinjau dari kompetensi guru terhadap menguasaan teknologi, ekonomi masyarakat yang juga terpuruk selama masa pandemi Covid 19, dan juga sektor penyebaran jaringan internet dengan kualitas baik yang belum merata diwilayah Indonesia.

\section{B. Pembahasan}

\section{Pembelajaran Dalam Jaringan}

Daring merupakan singkatan dari "dalam jaringan" sebagai pengganti kata online yang sering kita gunakan dalam berbicara teknologi internet. ${ }^{14}$ Daring adalah terjemahan dari istilah online yang bermakna tersambung ke dalam jaringan internet. Pembelajaran daring artinya adalah pembelajaran yang dilakukan secara online, menggunakan aplikasi pembelajaran maupun jejaring sosial. $^{15}$

Pembelajaran daring merupakan pembelajaran yang dilakukan tanpa melakukan tatap muka, tetapi melalui platform yang telah tersedia. ${ }^{16}$ Segala bentuk materi pelajaran didistribusikan secara online, komunikasi juga dilakukan secara online, dan tes juga dilaksanakan secara online. ${ }^{17}$ Daring juga menyatakan kondisi pada suatu alat perlengkapan atau suatu unit fungsional. ${ }^{18}$

\footnotetext{
${ }^{14}$ Mhd Isman, Pembelajaran Moda Dalam Jaringan (Moda Daring) (Muhammadiyah University Press, 2016).

15 Ibid.

${ }^{16}$ Poncojari Wahyono, H. Husamah, and Anton Setia Budi, 'Guru profesional di masa pandemi COVID-19: Review implementasi, tantangan, dan solusi pembelajaran daring', Jurnal Pendidikan Profesi Guru, vol. 1, no. 1 (2020).

${ }^{17}$ Carona Elianur, 'Pilihan Media Pembelajaran Daring Oleh Guru Pai Di Bengkulu Tengah', Jurnal As-Salam, vol. 4, no. 1 (2020), pp. 37-45.

18 Albitar Septian Syarifudin, 'Impelementasi Pembelajaran Daring Untuk Meningkatkan Mutu Pendidikan Sebagai Dampak Diterapkannya Social Distancing', Jurnal Pendidikan Bahasa dan Sastra Indonesia Metalingua, vol. 5, no. 1 (2020), pp. 31-4.
} 
Sebuah kondisi dikatakan daring apabila memenuhi beberapa persyaratan sebagai berikut ${ }^{19}$ :

a. Di bawah pengendalian langsung dari alat yang lainnya.

b. Di bawah pengendalian langsung dari sebuah sistem.

c. Tersedia untuk penggunaan segera atau real time.

d. Tersambung pada suatu sistem dalam pengoperasiannya,

e. Bersifat fungsional dan siap melayani.

Berdasarkan dari data yang telah dikumpulkan didapati bahwa Sebagian besar tenaga pendidik menggunakan Whatsaap Grup, Google meet, google form zoom sebagai platform pembelajaran daring. Selama pelaksanaan moda daring, peserta didik memiliki keleluasaan waktu untuk belajar. Peserta didik dapat belajar kapan pun dan dimana pun, tanpa dibatasi oleh ruang dan waktu. Peserta didik juga dapat berinteraksi dengan guru pada waktu yang bersamaan, seperti menggunakan video call atau live chat. ${ }^{20}$ Pembelajaran daring dapat disediakan secara elektronik menggunakan forum atau message. ${ }^{21}$

\section{Pembelajaran Luar Jaringan}

Pembelajaran di sekolah umumnya menggunakan metode tatap muka antara guru dan peserta didik untuk menyampaikan materi secara maksimal kepada peserta didik. Namun dalam situasi pandemi covid 19 metode tatap muka dihindari agar tidak menimbulkan penyebaran Covid 19. Dengan kata lain tidak selamanya pembelajaran bisa dilakukan secara tatap muka. ${ }^{22}$

Metode luar jaringan (luring) atau offline dapat membantu peserta didik untuk tetap belajar. Pembelajaran dengan metode Luring atau offline merupakan pembelajaran yang dilakukan di luar tatap muka oleh guru dan peserta didik,

\footnotetext{
${ }^{19}$ Oktafia Ika Handarini and Siti Sri Wulandari, 'Pembelajaran Daring Sebagai Upaya Study From Home (SFH) Selama Pandemi Covid 19’, Jurnal Pendidikan Administrasi Perkantoran (JPAP), vol. 8, no. 3 (2020), pp. 496503.

20 Batubara and Batubara, 'Penggunaan Video Tutorial Untuk Mendukung Pembelajaran Daring Di Masa Pandemi Virus Corona'.

${ }^{21}$ Minanti Tirta Yanti, Eko Kuntarto, and Agung Rimba Kurniawan, 'Pemanfaatan Portal Rumah Belajar Kemendikbud sebagai Model Pembelajaran Daring di Sekolah Dasar', Adi Widya: Jurnal Pendidikan Dasar, vol. 5, no. 1 (2020), pp. 61-8.

${ }^{22}$ Arifin, 'Sekolah di Rumah'.
} 
namun dilakukan secara offline. Sistematika pembelajarannya adalah guru memberikan materi berupa tugas hardcopy, file video pembelajaran, materi pembelajaran cetak ataupun menonton Televisi yang menyajikan acara materi pembelajaran. Kemudian diberikan kepada peserta didik dilaksanakan di luar sekolah. $^{23}$

Metode pembelajaran di luar sekolah atau luring ini salah satu metode yang dapat diterapkan sementara waktu untuk melakukan pembelajaran, namun materi yang diberikan oleh guru harus menarik, sehingga siswa tidak mudah bosan dan badmood. Hal ini karena ruang lingkup pembelajaran luring yang sempit, sehingga memerlukan kreatifitas guru menyajikan materi agar tetap menarik. sehingga dalam melakukan pembelajaran siswa merasa senang. ${ }^{24}$

Kegiatan Luring tidak menggunakan jaringan internet, melainkan media lainnya seperti Televisi (TV) dan dokumen. Adapun jenis kegiatan yang dilakukan pada proses pembelajaran luring bisa dengan menonton cara menonton acara stasiun televisi yang menyajikan materi pembelajaran, kemudianpembelajaran luring juga bisa diimplementasikan dengan cara mengumpulkan karya berupa dokumen selama masa sekolah dari rumah. Pembelajaran luring atau belajar secara mandiri harus sesuai dengan petunjukpetunjuk yang ada dalam bahan ajar "manual" seperti Modul, Lembar Kerja Peserta Didik (LKPD) dan bisa juga dengan menonton video-video pembelajaran yang bisa diputar tanpa jaringan internet. ${ }^{25}$

Guru mata pelajaran menyiapkan modul, LKPD, tugas siswa, menyerahkan tugas untuk siswa kepada wali kelas dan melakukan penilaian. Guru mata pelajaran bertugas untuk membuat modul (bahan ajar) yang sesuai dengan materi yang akan dipelajari oleh siswa, membuat LKPD yang mudah dipahami oleh siswa dalam mengerjakan tugas, dan memberikan tugas. selanjutnya Wali kelas mendistribusikan tugas kepada siswa mengumpulkan kembali hasil

\footnotetext{
${ }^{23}$ Gunawan, 'Transformasi Televisi Sebagai Masa Pandemi Covid-19'.

${ }^{24}$ Didin Widyartono, Tes Tertulis Kurikulum 2013 Berbasis Daring Dan Luring.

${ }^{25}$ Surtika, 'Praktik Merdeka Belajar dalam Situasi Covid-19 (Sebuah Pengalaman Memimpin dari Rumah dalam Situasi Pandemik Covid-19 di SMKN 1 Pacet)'.
} 
pekerjaan siswa, menyerahkan hasil pekerjaan siswa kepada guru mata pelajaran, serta merekap nilai siswa dan melaporkan kepada orang tua siswa. ${ }^{26}$

Pada saat pendistribusian atau mengumpulkan kembali tugas-tugas dari siswa pada wali kelas maka diperlukan penjelasan-penjelasan yang berisikan keterangan-keterangan baik berupa materi, teknik dan cara mengumpulkan kembali masih perlu adanya pertemuan antara guru dengan peserta didik.

Untuk menunjang berhasilnya metode pembelajaran Luring, diperlukan kerjasama antara guru, murid dan wali murid itu sendiri. Komunikasi antara guru dan serta kolaborasi dengan wali murid, menjadi hal yang tak dapat dihindari. Hal ini dikarena proses pengawasan belajar siswa seutuhnya ada dalam jangkauan orang tua selama pandemi Covid 19. ${ }^{27}$

\section{Kesimpulan}

Berdasarkan uraian di atas dapat disimpulkan bahwa implementasi pembelajaran darimg selama Covid 19 banyak menggunakan aplikasi online seperti whatsaap, google form, google meet, zoom dalam proses kegiatan belajara mengajarnya. Sedangakn pembelajaran luring, diimplementasikan dengan cara pemberian tugas atau pun menonton acara TV, video pembelajaran yang tidak menggunakan jaringan internet.

\section{DAFTAR PUSTAKA}

Arifin, Syamsul, 'Sekolah di Rumah', Arsip Publikasi Ilmiah Biro Administrasi Akademik, 2020.

Atiqoh, Lia Nur, 'Respon Orang Tua Terhadap Pembelajaran Daring Pada Masa Pandemi Covid-19', Thufuli: Jurnal Ilmiah Pendidikan Islam Anak Usia Dini, vol. 2, no. 1, 2020, pp. 45-52.

Badriyah, Nadia Fairuz, Aplikasi Android Luring Cifra Berbasis Multimedia Interaktif Untuk Pembelajaran Civilisation Française, Universitas Pendidikan Indonesia, 2018.

Batubara, Hamdan Husein and Delila Sari Batubara, 'Penggunaan Video Tutorial

\footnotetext{
${ }^{26}$ Nadia Fairuz Badriyah, Aplikasi Android Luring Cifra Berbasis Multimedia Interaktif Untuk Pembelajaran Civilisation Française (Universitas Pendidikan Indonesia, 2018).

${ }^{27}$ Lia Nur Atiqoh, 'Respon Orang Tua Terhadap Pembelajaran Daring Pada Masa Pandemi Covid-19', Thufuli: Jurnal Ilmiah Pendidikan Islam Anak Usia Dini, vol. 2, no. 1 (2020), pp. 45-52.
} 
Untuk Mendukung Pembelajaran Daring Di Masa Pandemi Virus Corona', Muallimuna: Jurnal Madrasah Ibtidaiyah, vol. 5, no. 2, 2020, pp. 74-84.

Dewi, Wahyu Aji Fatma, 'Dampak Covid-19 terhadap implementasi pembelajaran daring di Sekolah Dasar', Edukatif: Jurnal Ilmu Pendidikan, vol. 2, no. 1, 2020, pp. 55-61.

Elianur, Carona, 'Pilihan Media Pembelajaran Daring Oleh Guru Pai Di Bengkulu Tengah', Jurnal As-Salam, vol. 4, no. 1, 2020, pp. 37-45.

Gunawan, I. Gede Dharman, 'Transformasi Televisi Sebagai Masa Pandemi Covid19', COVID-19: Perspektif Pendidikan, Yayasan Kita Menulis, 2020, p. 79.

Handarini, Oktafia Ika and Siti Sri Wulandari, 'Pembelajaran Daring Sebagai Upaya Study From Home (SFH) Selama Pandemi Covid 19', Jurnal Pendidikan Administrasi Perkantoran (JPAP), vol. 8, no. 3, 2020, pp. 496503.

Isman, Mhd, Pembelajaran Moda Dalam Jaringan (Moda Daring), Muhammadiyah University Press, 2016.

Pangondian, Roman Andrianto, Paulus Insap Santosa, and Eko Nugroho, 'FaktorFaktor Yang Mempengaruhi Kesuksesan Pembelajaran Daring Dalam Revolusi Industri 4.0', Seminar Nasional Teknologi Komputer \& Sains (SAINTEKS), vol. 1, 2019.

Rigianti, Henry Aditia, 'Kendala Pembelajaran Daring Guru Sekolah Dasar Di Banjarnegara', Elementary School: Jurnal Pendidikan dan Pembelajaran keSD-an, vol. 7, no. 2, 2020.

Sadikin, Ali and Afreni Hamidah, 'Pembelajaran Daring di Tengah Wabah Covid19', BIODIK, vol. 6, no. 2, 2020, pp. 109-19.

Sanjaya, Ridwan, 21 Refleksi Pembelajaran Daring di Masa Darurat, SCU Knowledge Media, 2020.

Sidauruk, Paraden Lucas, 'Peranan Komunikasi Dalam Implementasi Kebijakan

Pusat Layanan Internet Kecamatan (Kasus di Provinsi Kepulauan Bangka Belitung)', Jurnal Penelitian Pos dan Informatika, vol. 3, no. 1, 2013, pp. 81-113.

Situru, Roberto Salu, 'Pembelajaran Dalam Jaringan (Daring) Masa Pandemic Covid-19', Elementary Journal, vol. 3, no. 1, 2020, pp. 40-6.

Surtika, Ida Yuniati, 'Praktik Merdeka Belajar dalam Situasi Covid-19 (Sebuah Pengalaman Memimpin dari Rumah dalam Situasi Pandemik Covid-19 di SMKN 1 Pacet)', simpuljuara, vol. 2, no. 2, 2020, pp. 66-72.

Suyono, Suyono, 'Manajemen Pembelajaran Berbasis Daring Dalam Rangka Memutus Mata Rantai Penularan Covid-19 Di Perguruan Tinggi Swasta Lembaga Layanan Perguruan Tinggi (LLDikti) Wilayah Vii', EdHumanistics: Jurnal Ilmu Pendidikan, vol. 5, no. 1, Fakultas Ilmu Pendidikan Universitas Hasyim Asy'ari Tebuireng Jombang, 2020, pp. 662-6.

Syarifudin, Albitar Septian, 'Impelementasi Pembelajaran Daring Untuk Meningkatkan Mutu Pendidikan Sebagai Dampak Diterapkannya Social Distancing', Jurnal Pendidikan Bahasa dan Sastra Indonesia Metalingua, vol. 5, no. 1, 2020, pp. 31-4. 
Wahyono, Poncojari, H. Husamah, and Anton Setia Budi, 'Guru profesional di masa pandemi COVID-19: Review implementasi, tantangan, dan solusi pembelajaran daring', Jurnal Pendidikan Profesi Guru, vol. 1, no. 1, 2020.

Widyartono, Didin, Tes Tertulis Kurikulum 2013 Berbasis Daring Dan Luring.

Yanti, Minanti Tirta, Eko Kuntarto, and Agung Rimba Kurniawan, 'Pemanfaatan Portal Rumah Belajar Kemendikbud sebagai Model Pembelajaran Daring di Sekolah Dasar', Adi Widya: Jurnal Pendidikan Dasar, vol. 5, no. 1, 2020, pp. $61-8$. 